\title{
PENGGUNAAN LEMBAR PRAKTIKUM TERBIMBING DALAM MATA KULIAH APLIKASI KOMPUTER UNTUK MENINGKATKAN PRESTASI BELAJAR MAHASISWA
}

\author{
Reza Kusuma Setyansah \\ Program Studi Pendidikan Matematika FPMIPA IKIP PGRI Madiun \\ Email : rezasetyansah@gmail.com
}

\begin{abstract}
Abstrak
Penelitian ini dilaksanakan sebagai pelaksanaan upaya pengembangan profesionalisme dosen dalam rangka proses penanaman nilai kemandirian belajar kepada mahasiswa melalui sebuah proses pembelajaran yang dilakukan oleh sekelompok dosen secara kolaboratif dan berkesinambungan dalam merencanakan, melaksanakan, mengobservasi dan melaporkan hasil pembelajaran.

Pengamatan penelitian tersebut menggunakan Penelitian Tindakan Kelas (PTK) yang terdiri dari empat siklus. Pada masing-masing penerapan program kajian pembelajaran terdapat 4 siklus yang memiliki empat tahap yaitu, tahap perencanaan, tahap pelaksanaan, tahap pengamatan dan tahap refleksi. Subjek penelitian ini adalah mahasiswa semester genap (kelas V-H) tahun akademik 2012/2013 yang berjumlah 39 orang. Adapun teknik pengumpulan data dilakukan dengan tes. Analisa data yang dilakukan adalah analisis diskriptif kualitatif.

Dari hasil penelitian 39 orang mahasiswa pada siklus I diperoleh banyaknya mahasiswa yang tuntas adalah 33,33\% dan 66,67\% mahasiswa yang tidak tuntas.Pada siklus II diperoleh banyaknya mahasiswa yang tuntas adalah $23,08 \%$ dan $76,92 \%$ mahasiswa yang tidak tuntas. Pada siklus III diperoleh banyaknya mahasiswa yang tuntas adalah 79,49\% dan 20,51\% mahasiswa yang tidak tuntas. Pada siklus IV diperoleh banyaknya mahasiswa yang tuntas adalah 82,05\% dan 17,95\% mahasiswa yang tidak tuntas. Hal ini menunjukkan adanya peningkatan yang cukup berarti. Pada perlakuan Siklus II dan siklus III selain terdapat peningkatan prestasi, penerapan lembar praktikum terbimbing mampu meningkatkan kemandirian belajar dan prestasi belajar mahasiswa dalam perkuliahan aplikasi komputer pada materi program matlab.
\end{abstract}

Kata kunci : Lembar Praktikum Terbimbing, Aplikasi Komputer, Prestasi Belajar.

\section{PENDAHULUAN}

Pendidikan merupakan hal yang sangat penting dewasa ini. Perkembangan saat ini menuntut manusia untuk memiliki potensi diri yang sangat tinggi agar tercapainya mutu kehidupan seseorang. pada umumnya model pembelajaran yang diterapkan dosen cenderung berpusat pada dosen (lecture centered) sehingga mahasiswa kurang aktif dalam proses belajar mengajar. Hal ini tentunya berdampak potensi diri mahasiswa yang berpengaruh pada prestasi belajar matematika mahasiswa.

Akhir-akhir ini telah dikembangkan modelmodel pembelajaran sebagai upaya meningkatkan keberhasilan dalam pembelajaran matematika. Dalam model pembelajaran penggunaan lembar praktikum terbimbing memberikan pengaruh dalam proses pembelajaran, diharapkan mahasiswa membentuk kemandirian belajar dan mampu mendorong potensi diri mahasiswa dalam berpikir, kreatif dan memahami yang diajarkan oleh dosen. Berkaitan dengan masalah kemandirian belajar, pemerintah sebenarnya telah berupaya untuk melaksanakan tindakantindakan yang bersifat preventif, salah satunya yaitu melalui program pendidikan. Program tersebut memuat beberapa integritas potensi diri yang perlu dimiliki oleh mahasiswa, beberapa diantaranya adalah potensi jujur, 
percaya diri, tanggung jawab, dan motivasi. Hal tersebut juga tercermin di dalam UU Nomor 20 Tahun 2003 tentang Sistem Pendidikan Nasional Pasal 3 yang menyatakan bahwa: Pendidikan Nasional berfungsi mengembangkan kemampuan dan membentuk watak serta peradaban bangsa yang bermartabat dalam rangka mencerdaskan kehidupan bangsa, bertujuan untuk berkembangnya potensi peserta didik agar menjadi manusia yang beriman dan bertaqwa kepada Tuhan Yang Maha Esa, berakhlak mulia, sehat, berilmu, cakap, kreatif, mandiri, dan menjadi warga negara yang demokratis serta bertanggungjawab.

Beberapa fakta di lapangan belum sepenuhnya terwujudnya mahasiswa memiliki kemandirian belajar sesuai dengan harapan tersebut. Salah satu contohnya di dalam Lembaga IKIP PGRI Madiun pada Program Studi Pendidikan Matematika, dimana masih banyak terdapat mahasiswa yang belum mampu melakukan diskusi belajar di luar kelas kuliah ataupun di dalam kelas kuliah. Hal ini nampak ketika dalam pembelajaran masih terdapat mahasiswa yang kurang mampu berkomunikasi dan bekerjasama dengan baik ketika mengikuti proses belajar.

Di sisi lain masih nampak sistem pembelajaran yang dilakukan oleh dosen juga masih cenderung mengabaikan hal-hal yang berkaitan dengan peningkatan kualitas pembelajaran, khususnya terkait dengan upayaupaya penanaman potensi diri pada mahasiswa. Terlebih lagi hal tersebut juga didukung dengan kurangnya perhatian dosen dalam mengembangkan kegiatan pembelajaran yang cenderung menggunakan metode ceramah dan sistem pengadaan ujian yang relatif memberikan keleluasaan bagi mahasiswa untuk berbuat tidak percaya diri dalam mengerjakan ujian. Senada dengan hal tersebut, Surat kabar harian Kompas (2012) mengungkapkan bahwa tidak meratanya pendidikan juga mengakibatkan kualitas masyarakat Indonesia tertinggal dibandingkan dengan negara lain. Padahal pendidikan merupakan faktor utama dalam membangun karakter bangsa dan faktor untuk menggerakkan perekonomian suatu bangsa. Berdasarkan data, perkembangan pendidikan Indonesia masih tertinggal bila dibandingkan dengan negara-negara berkembang lainnya. Menurut Education For All Global Monitoring Report 2011 yang dikeluarkan oleh UNESCO setiap tahun dan berisi hasil pemantauan pendidikan dunia, dari 127 negara, Education Development Index (EDI) Indonesia berada pada posisi ke-69. Indonesia kalah dibandingkan Malaysia (65) dan Brunei (34). Begitu pula berdasarkan laporan United Nation Development Program (UNDP) tahun 2005, yang mengungkapkan bahwa kualitas Sumber Daya Manusia (SDM) di Indonesia menempati posisi ke-109 dari 117 negara (Istamar Syamsuri, 2010). Hal itu mengindikasikan bahwa jika kualitas SDM rendah, maka kualitas pendidikan di Indonesia juga relatif masih rendah.

Harapan peneliti dengan adanya strategi pembelajaran dengan penggunaan lembar praktikum terbimbing akan memberikan dampak yang positif dalam perkembangan pemahaman mahasiswa yang umumnya apabila menerima materi perkuliahan secara langsung khususnya pada mata kuliah aplikasi komputer yang terdiri dari beberapa langkah-langkah penerapan dan pola pengembangan berpikir berdasarkan kasus-kasusnya akan sulit menerima hal tersebut. Hal ini akan lebih mudah dipahami dan terima oleh mahasiswa terhadap materi-materi perkuliahan aplikasi komputer khususnya dengan strategi pembelajaran dengan penggunaan lembar praktikum terbimbing.

Secara umum, manfaat penggunaan lembar praktikum terbimbing dalam proses 
pembelajaran adalah melatih mahasiswa untuk belajar mandiri dengan beberapa mentoring dari dosen terhadap beberapa langkah-langkah penerapan dan kasus-kasus dalam materi perkuliahan aplikasi komputer, sehingga kegiatan pembelajaran akan lebih efektif dan efisien.

\section{METODE}

\section{Tempat dan Subjek Penelitian}

Tempat pelaksanaan penelitian ini di IKIP PGRI Madiun. Subjek penelitiannya adalah mahasiswa kelas V-H semester ganjil tahun ajaran 2012/2013.

\section{Rancangan Pelaksanaan Siklus}

Jumlah siklus yang dirancang pada penelitian ini menerapkan siklus pembelajaran sebanyak 4 kali. Pada masing-masing siklus terdiri dari kegiatan perencanaan, pelaksanaan tindakan (observasi) dan evaluasi refleksi.

\section{Gambar. 1 Rekapitulasi Siklus Ketuntasan Belajar Mahasiswa}

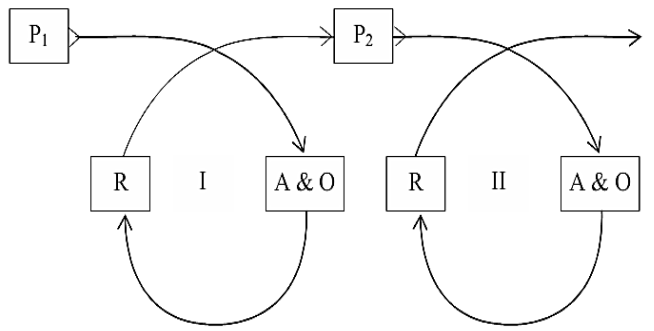

\section{Keterangan :}

$\mathrm{P}_{1} \quad$ : Perencanaan ke 1

$\mathrm{P}_{2} \quad$ : Perencanaan ke 2

A \& O : Pelaksanaan dan Observasi

R : Refleksi dan evaluasi

\section{Teknik dan Instrumen Pengumpulan Data}

Pengumpulan data menggunakan teknik observasi dengan menggunakan lembar pengamatan yang telah dirancang pada saat perencanaan. Lembar pengamatan tersebut digunakan untuk merekam aktivitas mahasiswa dan dosen dalam kegiatan pembelajaran.

\section{Prosedur Penelitian}

Dalam prosedur penelitian ini terdiri atas empat siklus, yang masing-masing siklus meliputi; perencanaan, pelaksanaan tindakan, observasi dan evaluasi refleksi.

\section{Analisis Data}

Analisis data dilakukan untuk mengetahui bagaimana cara mengolah data yang diperoleh serta menentukan rumus statistik yang berhubungan dengan penelitian ini. Data yang dianalisis adalah data hasil tes belajar mahasiswa pada setiap akhir siklus. Penilaian tes dilakukan untuk menilai perorangan (individu). Berdasarkan Standart Kriteria Ketuntasan Minimal (KKM) di IKIP PGRI Madiun, mahasiswa dikatakan tuntas dalam belajar apabila siswa tersebut memperoleh nilai $\geq 65$.

Kualifikasi hasil ketuntasan prestasi belajar mahasiswa sesuai dengan tabel berikut:

Tabel 2. Klasifikasi Ketuntasan Belajar Mahasiswa

\begin{tabular}{ccc}
\hline No & $\begin{array}{c}\text { Rentang persentase } \\
\text { skor yang diperoleh }\end{array}$ & Kualifikasi \\
\hline 1 & $85 \%-100 \%$ & Sangat Baik \\
\hline 2 & $65 \%-85 \%$ & Baik \\
\hline 3 & $45 \%-65 \%$ & Cukup \\
\hline 4 & $25 \%-45 \%$ & Kurang \\
\hline 5 & $<25 \%$ & Sangat Kurang
\end{tabular}

Respons mahasiswa dikatakan tuntas jika persentase prestasi belajar mahasiswa yang diperoleh termasuk dalam kualifikasi baik/sangat baik. Apabila hasil pekerjaan mahasiswa baik/sangat baik dengan rata-rata mencapai $75 \%$ berarti penelitian berhasil.

\section{Hasil Penelitian dan Pembahasan}

Berdasarkan hasil pengamatan dari beberapa siklus yang telah dilaksanakan oleh dosen model, dapat dirangkum rekapitulasi 
ketuntasan hasil belajar mahasiswa sebagai berikut:

Tabel 3. Rekapitulasi Siklus Belajar Mahasiswa

\begin{tabular}{ccccc}
\hline SIKLUS & Siklus I & Siklus II & Siklus III & Siklus IV \\
\hline Tuntas & $33,33 \%$ & $23,08 \%$ & $79,49 \%$ & $82,05 \%$ \\
\hline $\begin{array}{c}\text { Tidak } \\
\text { Tuntas }\end{array}$ & $66,67 \%$ & $76,92 \%$ & $20,51 \%$ & $17,95 \%$ \\
\hline
\end{tabular}

Gambar. 2 Rekapitulasi Siklus Ketuntasan Belajar Mahasiswa

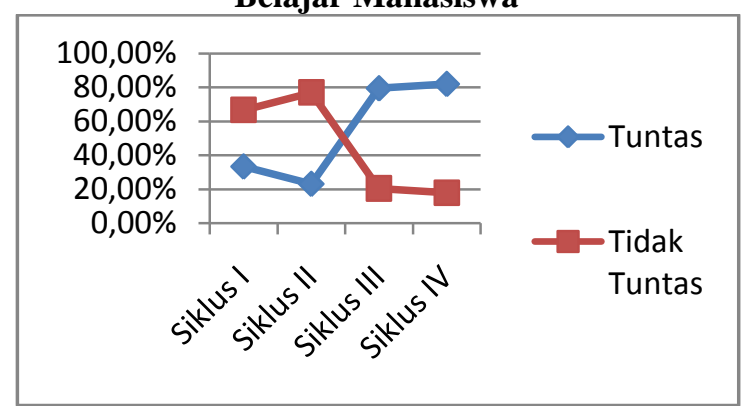

Dari hasil rekapitulasi prosentase ketuntasan belajar mahasiswa pada materi program matlab pada mata kuliah aplikasi komputer di atas, dapat diketahui bahwa terjadi peningkatan ketuntasan mahasiswa dalam hasil evaluasi belajarnya dalam penggunaan lembar praktikum terbimbing. Hal ini mengindikasikan bahwa pada setiap siklus, mahasiswa mengalami peningkatan pemahaman terhadap materi, sehingga dalam hal ini kemandirian belajar mahasiswa terdapat peningkatan. Berdasarkan pengamatan hasil prestasi belajar mahasiswa dapat menyelesaikan soal tes yang diberikan oleh dosen dengan baik. Namun hal ini perlu menjadi penelitian lebih lanjut guna menelusuri perkembangan peningkatan aktivitas belajar mahasiswa, khususnya terhadap mata kuliah aplikasi komputer.

Terlepas dari hal tersebut, tentu saja beberapa upaya yang telah dilakukan oleh dosen juga memberikan pengaruh yang baik terhadap pemahaman materi oleh mahasiswa pada setiap siklus apabila dibandingkan dengan siklus sebelumnya. Upaya-upaya tersebut diantaranya: pembelajaran dengan model berkelompok, pemberian lembar praktikum terbimbing dan tugas secara individu untuk langsung mengaplikasikan hasil diskusi secara individu di depan kelas dan tidak tergantung atau terpengaruh hasil jawaban antar individu yang lain.

\section{KESIMPULAN}

a) Adanya peningkatan motivasi belajar mahasiswa dalam pembelajaran mata kuliah aplikasi komputer menggunakan lembar praktikum terbimbing pada semester V-H IKIP PGRI Madiun tahun akademik 2012/2013. Hal ini terlihat dari semangat dan kemandirian belajar mahasiswa dalam menerapkan lembar praktikum terbimbing terhadap materi kuliah aplikasi komputer.

b) Adanya peningkatan aktivitas belajar mahasiswa dalam pembelajaran mata kuliah aplikasi komputer menggunakan lembar praktikum terbimbing pada semester V-H IKIP PGRI Madiun tahun akademik 2012/2013. Hal ini terlihat dari pengaruh aktivitas belajar mahasiswa dalam menerapkan lembar praktikum terbimbing terhadap materi kuliah aplikasi komputer.

c) Adanya peningkatan prestasi belajar mahasiswa dalam pembelajaran mata kuliah aplikasi komputer menggunakan lembar praktikum terbimbing pada semester V-H IKIP PGRI Madiun tahun akademik 2012/2013. Hal ini terlihat dari peningkatan nilai rata-rata hasil tes/kuis akhir kegiatan pembelajaran mahasiswa setelah menerapkan lembar praktikum terbimbing terhadap materi kuliah aplikasi komputer setiap siklusnya.

\section{SARAN}

a) Dosen hendaknya mampu melakukan inovasi-inovasi dalam kegiatan 
pembelajarannya, misalnya dengan melakukan kolaborasi dengan dosen lain yang diharapkan akan dapat saling bertukar pikiran guna peningkatan profesionalismenya dalam statusnya sebagai seorang tenaga pendidik maupun tenaga pengajar.

b) Mahasiswa hendaknya menyadari akan pentingnya mata kuliah yang menjadi prasyarat bagi mata kuliah selanjutnya, sehingga diharapkan akan lebih membantu memperlancar kegiatan belajar mengajar di kelas.

c) Bagi peneliti lain hendaknya mengambil materi yang berbeda atau menerapkan pada kelas yang berbeda untuk mengetahui apakah penerapannya memberikan hasil yang lebih baik atau tidak.

d) Keterbatasan penelitian, dalam penerapan pembelajaran menggunakan lembar praktikum terbimbing masih sangat jauh dari sempurna maka penerapan perlu diuji cobakan pada kelas yang lain dan membutuhkan penyesuaian ketercapaian indikator terutama masih banyak mahasiswa yang kurang teliti dalam menginput aplikasi perintah dalam praktikum maupun mengerjakan soal terutama dalam perintah ataupun pemberkasan data.

\section{DAFTAR PUSTAKA}

Istamar Syamsuri. 2010. Peningkatan Kompetensi Guru Untuk Meningkatkan Minat Siswa Pada Bidang Mipa. Makalah disampaikan dalam Lokakarya MIPAnet 2010, The Indonesian Network of Higher Educations of Mathematics and Nanutal Sciences, tanggal 26-27 Juli 2010, di IPB, Bogor.

Kompas.com. Pendidikan Tak Merata, Kualitas Masyarakat Tertinggal. http://edukasi.kompas.com/read/2012/0 9/13/16333195/Pendidikan.Tak.Merata Kualitas.Masyarakat.Tertinggal. diakses tgl 07 November 2012.

UU Nomor 20 Tahun 2003 tentang Sistem Pendidikan Nasional Pasal 3. 